Regards sur l'économie allemande

Bulletin économique du CIRAC

107 | 2012

Varia

\title{
Réseaux sociaux : un Allemand sur 2 en est membre
}

\author{
Isabelle Bourgeois
}

\section{OpenEdition}

Journals

Édition électronique

URL : http://journals.openedition.org/rea/4500

DOI : $10.4000 /$ rea. 4500

ISBN : 978-2-8218-1424-0

ISSN : 1965-0787

Éditeur

CIRAC

Édition imprimée

Date de publication : 20 décembre 2012

Pagination : 38

ISSN : 1156-8992

Référence électronique

Isabelle Bourgeois, "Réseaux sociaux : un Allemand sur 2 en est membre », Regards sur l'économie allemande [En ligne], 107 | décembre 2012, mis en ligne le 14 janvier 2013, consulté le 15 septembre 2020. URL : http://journals.openedition.org/rea/4500

Ce document a été généré automatiquement le 15 septembre 2020.

(C) CIRAC 


\title{
Réseaux sociaux : un Allemand sur 2 en est membre
}

\author{
Isabelle Bourgeois
}

1 En Allemagne aussi, les réseaux sociaux ont le vent en poupe. Depuis 2008, le nombre d'utilisateurs a triplé pour atteindre aujourd'hui $47 \%$ chez les 14-64 ans. Le réseau préféré des Allemands est Facebook ( $88 \%$ du total). Si ce sont principalement les jeunes qui pratiquent les réseaux sociaux ( $80 \%$ des 14-29 ans), les plus âgés ne sont pas en reste, avec 56 \% des 30-39 ans et même $21 \%$ des 50-64 ans. Ce mode de communication est largement entré dans les mœurs; de moins en moins d'Allemands peuvent encore "imaginer vivre sans les réseaux sociaux»: les plus jeunes ( $51 \%$ des 14-19 ans) moins cependant que les plus âgés (21\% des 60-69 ans).

2 Ces taux de réponses restent inférieurs, bien sûr, à ceux qui concernent l'usage du téléphone portable : $73 \%$ de la première catégorie ne peuvent s'imaginer vivre sans, et même 49 \% à l'autre extrême. L'usage de l'Internet mobile est également de plus en plus répandu (+ $80 \%$ en un an) : un tiers des Allemands de tous âges (31\%) surfe ainsi sur le Net, dont la majorité (29\%) via un smartphone. Ces taux ont doublé en l'espace d'un an. Et $7 \%$ des Allemands consultent désormais Internet via leur Tablet PC; ils n'étaient encore que $2 \%$ l'an passé.

3 L'usage d'Internet est aujourd'hui standard : les Allemands surfent le plus souvent pour effectuer des achats en ligne (74\%) ou pour s'informer sur les prix et produits (71 \%). La quête d'information gagne du terrain elle aussi : 6,6 \% d'entre eux téléchargent les apps de la presse écrite ou audiovisuelle. C'est ce qu'il ressort de la dernière vague de l'enquête ACTA réalisée par l'Institut für Demoskopie d'Allensbach auprès de près de 9000 Allemands de 14 à 69 ans (www.ifd-allensbach.de/acta). 
INDEX

Mots-clés : média, réseau social, nouvelles technologies, Internet, nouveau média, groupe social, statistique 